26B.-

Stopyor

P Z 10

.5649 $\mathrm{S}$
FT MEADE GenColl 

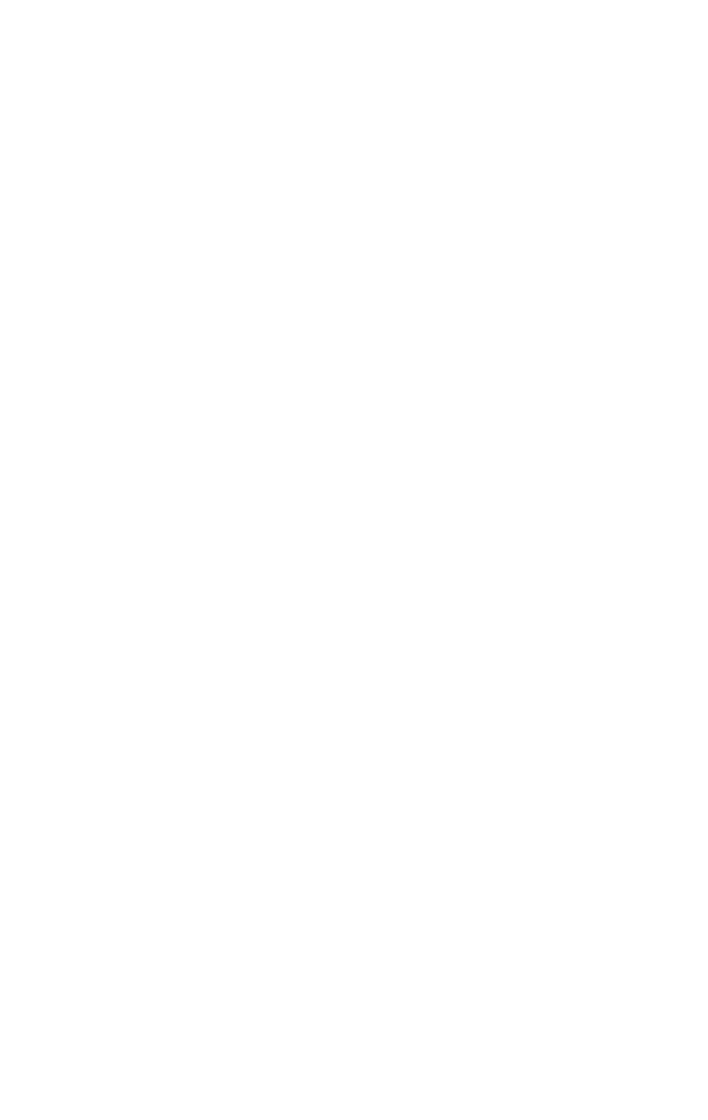





\title{
BOOKS FOR CHILDREN
}

\author{
ALSO
}

POETRY, STORY AND DRAMA

STORY OF BLACKIE. 4th Edition. BLACKIE'S COMPANIONS. STORIES OF FIDO AND HUNTER.

DAY LILIES. Poems. THE MAYOR OF KANEMETA. Story. DONALD MONCRIEF. A FOREST IDYL. Story. THE SEAL OF HELlaS. Classical Drama. SONNETS OF LIFE. Poems. 



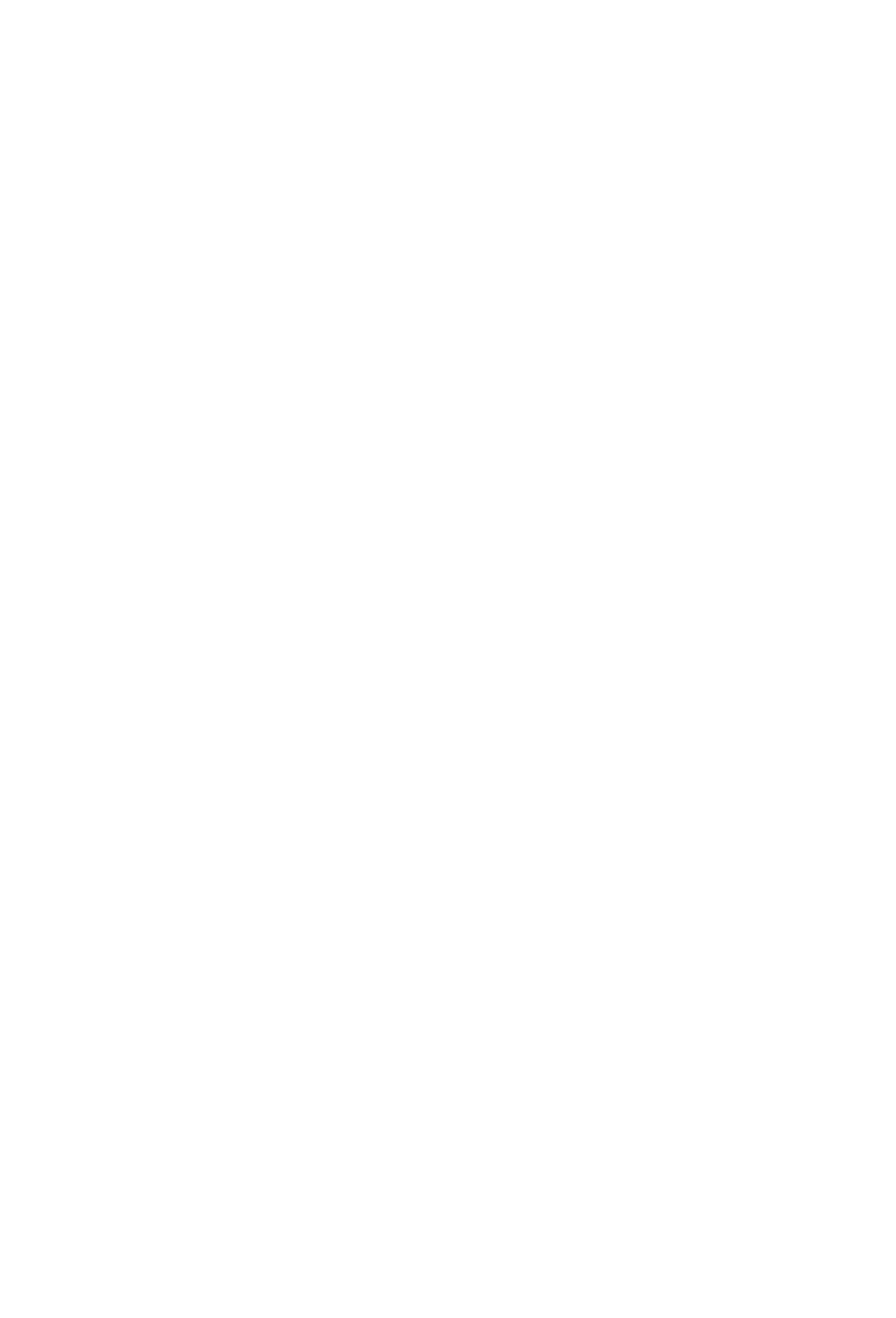




\title{
THE STORY OF ZEPHYR
}

A Christmas Story

\author{
BY \\ (Darden) \\ JEANIE OLIVER SMITH \\ "Temple Oliver"
}

NEW YORK

I9I7 


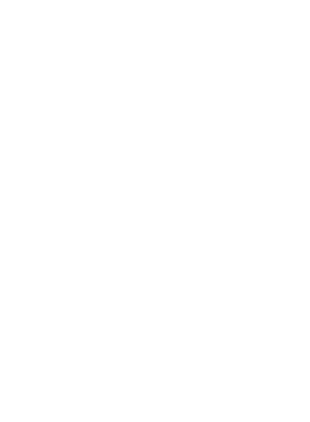

Copyright, IgI7

JEANIE OLIVER SMITH

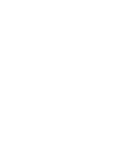

DEC 151917

(C)CI.A481016 
TO

GEORGIA JOHNSON HENRY 



\title{
THE STORY OF ZEPHYR
}

A Christmas Story

\section{CHAPTER I}

\author{
EDWY'S WISH
}

"FAther, "may I have an English setter for my Christmas present?"

Edwy spoke in a subdued tone, for the president of a certain Association, a country club, of which his father was a member, had come to say good-bye. One branch of the party of campers on the lake was about to break up; city schools were calling them from forest and from field.

The stranger had taken a seat on the broad veranda, his dog at his heels, his carriage and horses waiting. 
Bruno knew his little friend Edwy. The boy stood stroking the dog's ears and speaking gentle words to him. The dog seemed to listen but although he was all attention and laid his head down on crossed paws, one eye was alert for the movements of his master.

A dog, an English setter like Bruno, was one thing which Edwy had sought with constant iteration since he was old enough to talk; especially since he had seen the devotion of Bruno for his master and even his master's horses. He had also gained the dog's confidence towards himself.

Edwy's mother felt that she must not let him keep on hoping for the impossible. They could not take a dog to a city home while they were building the camp on the lake. It was equally out of the question either, to carry him back and forth on the cars, or to leave him at home with servants while all the family were away.

As he stood stroking the dog's ears and 


\section{7}

speaking his own little tender words to him, the watchful mother explained, aside, the reason of the refusal.

"You know, Edwy, a dog gets so terribly homesick if left in the care of servants. Just see how Bruno is waiting to leap to his master's side, and fly down the road the moment the horse's hoofs ring on the highway. .... When you are older. ..."

How Edwy hated the words, "when you are older!" It always meant that you couldn't have something when you wanted it. But as he was a well-bred child, he always kept quiet in company. He had sometimes confided to Willard, his brother, but that didn't help much.

"Could I have a kitten then? I do want some kind of a thing that isn't either damb or dead." A certain chum of Edwy's-not the usual kind of a chum-but one in his own and Willard's estimation well worthy of the name, had noticed the fact that the child 
8

had so bravely banished the frown of disappointment. She had also noted the fact that no ban had been placed against a kitten, and a plan was forming in her mind, but she did not divulge it. 


\section{CHAPTER II}

\section{THE LITTLE TRAPPER}

EDwy had been called "The Little Trapper." He had read every book he could find about animals. After reading some of them, he would be the "warrior bold"; would long tc be old enough to shoot and slay and pursue big game through the forest spaces, but bless his heart, he hadn't the least idea that there was any tragedy in it. He had made box-traps with his own hands, but in such a way, however, that it would hardly frighten the little creatures to be caught, for he would only keep the little prisoners an hour, or a minute perhaps, feed them, and let them go free.

One day he had found in his trap a pretty brown-eyed musk-rat, and the creature found 
himself liberated beside his own stream, not a bit the worse for its experience. And one day he found a strange slate-colored dormouse, but it had managed to get out of its cage by its own ingenuity or some one's help. Another day he caught several little squirrels, first getting one, then another, and another, and letting them pass by a bridge of his own or his father's contriving, from one box to another, but they were all to be set free in a short time and seemed to think it was mere play. At first they seemed to try to tease each other, their comrades, for the moment. He had discovered that in this first stage they would not eat, but after a while he had rushed into the house to tell Willard his new discovery.

"Why, Willard, they've all got acquainted with each other, and they know me. They seem to know that I don't mean to hurt them, and now they 'grab' for everything I offer them to eat." 
It soon became evident that the squirrelfamilies would have to be more severely dealt with, for more than once they had disturbed the little birds on their nests, and in some cases had been known to destroy their eggs; so a plan was formed to transport one or two of the squirrel families to another portion of the woods, and thus leave the robins and the warblers in undisputed possession near the camp.

At length came the plans for the opening of the doors of the temporary trap, to introduce the squirrels to their new forest home.

Where the lake laps the shore, several rowboats were drawn up in line and it was but the work of a moment to embark, for all the interested members of the little group could enter readily into the child's feelings. The morning was one of the gems of June, with crystal sky and lake. As the boats sped out towards the further shore the wise little creatures in the box crowded further back, 
massed themselves in a bunch, their feet towards the opening of the box, their pointed noses quivering with excitement. Their little sharp bead-like eyes alert, but less full of fear than at first, for already they had grown familiar with a petting word from the little "trapper" and friend, and were fast growing trustful of their human kind.

Now the problem was to get them to cross the small channel of deep water which lay between them and the shore. A rustic bridge was made by means of a wide board, and then the doors were opened! Such a patter of little twinkling feet as they ran, one after another, "low geared" for the land, while the party sailed back or remained on the lake to enjoy the delights of rod and line, the feast of the flowers on the banks and the songs of numberless birds, all part of the glorious summer time. 


\section{CHAPTER III}

\section{A WELCOME GUEST}

Some weeks previous to this, while the campers still thought they had the whole summer before them, a little white kitten with gold spots, had come, seemingly from nowhere, and had sought admission-not to Edwy's camp-but to his Uncle's, across the lake.

His Uncle's wife was the dearest, the most , teasable aunt in the world. She was known sometimes as "Aida," from a pet name one of them had given her. They had never called her Aunt, but always some nice pet name and always pretended they didn't care a flip for her, but she knew better, for 
wasn't she their own mother's sister, who had also a pet name of her own? And were they not both daughters of this great chum of theirs, who, as their father had told them was entirely their own contemporary and equal, but at the same time they mustn't tease her or treat her as if they were playing football; and mustn't touch her pretty white dress with their "candy" fingers.

Edwy was glad that the kitten had come to visit them. He was afraid that the winter would be hard on the poor thing. ... Everybody said it could take care of itself, but why couldn't it take care of itself now? It came every morning, to ask them for food and would give its high-toned purr of satisfaction when they had fed it.

Much as Edwy liked it, he was glad that it had not come to his father's camp, for they had some little rabbits.

They had brought them, when old enough, from their own home, and had let them run 


\section{I5}

wild through the woods and underbrush, near the woods and the lake.

"But would you believe it, Willard?" he said to his brother, "they come back to our camp, just as soon as they hear my voice shouting to them, half a mile away, and then they begin to show up out of the underbrush."

It was always jolly at his Aunt's camp, for in his own camp, he feared the rabbits and the kitten might not agree, and he and Willard were quite as much at home in the one place as the other.

The only time when the kitten had visited their camp on the hill was once, when they had all been away a few days, and when both camps were empty for that length of time.

On coming back, the very first thing they saw, in front of Edwy's father's camp, was the little white kitten sitting on the door-step, crying a glad welcome to them, arching its 
back, and reaching up for them to pet it. Very soon Edwy took the megaphone from its corner and called over the lake....

\section{"Hello!"}

The sound of Aida's voice came floating back.

"Yes: I can hear you."

"We all thought our little Zephyr was lost, but she is here, all safe and sound; and she's had a bowl of milk. Willard and I are going to row the boat over the lake, and bring her back to your house, Aida, for that is her real home."

On reaching the other shore, Aida and Mo-ma were glad to welcome the boys with their pet, for they had all feared she was lost. She had found her way to the other house, along a wood road, they thought, all the way. If she had gone along the borders of the lake, it would have been much nearer, but it was swampy that way, so she must have taken the high road and had made 
friends with the tame rabbits, not hurting any of them.

The boys were well pleased with the result of their afternoon's visit, for Zephyr seemed so glad to get home, that she went through all her little antics for them, hiding under the wood pile, then leaping out to surprise them and glancing up in their faces almost as if she were laughing, trying races with them along the wooded shore. After the boys had partaken of the nice little lunch that Aida had planned for them, some cake and berries, crimson raspberries that had grown in the field by the road-side, it was time to take the boat for their homeward trip.

Zephyr followed them to the bank and looked after them as long as there was light enough to see the loat. Aida also, watching them off, and their dear mother outlined against the further shore, waiting their arrival. 


\section{CHAPTER IV}

\section{ZEPHYR "SECOND"}

Ir was Edwy himself who had named the cat Zephyr second. For one summer they had a cat visitor that he named Zephyr, but she had gone back to her home among the mountains and they had never seen her again. But for this little kitten that had come to them, so white, so pretty and engaging, a real snow-flake in color, so tiny and playful; Zephyr seemed such an appropriate name. He could not call it Zephyr alone, for that would have seemed like forgetting the former one, who was not so beautiful as this one, and had never leaped higher than one's head like this one, but Zephyr second, or Zephyr II, would be quite the thing, and keep the former one in memory. 
He was glad that this one had come to his Aunt Aida's, for they would be a month longer in camp, and then Zephyr's winter would not seem so long.

He seemed more and more appreciative of all the graceful pranks of his pet when she ran like a wild happy thing, leaping up as high as the fence posts after butterflies in the sunshine, running up to the very tops of the trees, and back again, but never catching the birds, oh no; she was too happy to lie in wait for them, and the best trick of all was, when she would sit on the bank and watch for a boat coming from the other camp, every time he and Willard were out of her sight. She would listen for the lapping of the oars, then leap to the bank, give a glad little cry, arch her back, and give her sweet, high-toned purr when they came near.

One evening before it was quite dark, when supper was just ready at their father's camp on the hill, Aida and Mo-ma had come 
over to stay all night. They were to have their even-song, with the organ, violin, and guitar, and the sweet human sympathetic voices of all in unison. The songs which Edwy was sure "could be heard by the birds in their nests high up in the tall trees, that leaned over the camp roof."

They had just heard Willard and his father, fastening their boat at the foot of the hill, and now they, "the truants," were running quickly up the stone steps from the landing, when Willard, the first comer, opened the door and thrust some object inside.

It was none other than Zephyr!

"While we were passing your dock, we saw Zephyr waiting all alone on the bank. We called to her, and she came running down and we took her right into the boat with us, and here she is!"

"You precious darling," said Edwy, stroking her.

As supper was now ready, he took her in 
his lap, and, contrary to all rules, he fed her, as the poet Maeterlinck used to do with his pet cat, talking to her in his happy voice in his own place at the table.

The evening had grown cool enough to have a fire of apple-tree wood, blazing before the broad hearth, so before they began their even-song, Willard had laid the moss-covered logs together and lighted them, removing first the dainty fender, which his own hands had made, with artistic deftness; having woven in the name of their camp among the interstices of the woven wire. Now, where the welcome fire-glow shone through it on the hearth-rug, Zephyr had taken her position, quite at home and happy; purring her "grey thrums," louder than ever, in her zontentment. 


\section{CHAPTER V}

THE REAL MEANING OF CHRISTMAS

IT seemed now as if this second camp, where Zephyr lived, had new attractions for Edwy. He would spend the days happily with his friends.

Here was that teasable aunt Aida, and his friend, "Mo-ma"; his own little conceit to avoid the longer name, but then he had as many pet names for her, as there were months in the year. She never held up other boys to them as examples, for she always seemed to think that he and Willard were the "best ever."

But it was drawing near the time that one branch of the family of campers would have to say good-bye to summer fields and woods, and go back to the city and school. Edwy 
felt a little blue about leaving his pets and had a quiet talk with this special friend of his, after the rest had gone out on the lake to have a last chance at the trout fishing, before leaving the lake.

He was in the reminiscent mood that precedes sleep, and was telling his friend how much he wished they would always stay in the country.

"But, after all, you would miss the bright, happy Christmas, in the city home, you know."

"Oh yes, to be sure, and we'll have the lovely snowflakes coming down from the sky, and a lot of good times."

She had asked him then, when they were talking about Christmas, and about all the delights of that time, if he knew the real meaning of Christmas.

"Why yes," he had answered. "It is to keep in mind a very great event in the world, the greatest that ever happened. But then, 
you know, it wouldn't be Christmas to us boys, if we didn't get some gifts of our very own, for we can't always be thinking 'big thoughts.'

"So many things," he continued, "were impossible until he was older. He had wanted a dog, but he couldn't have that. He had asked for a cat, but, of course, he couldn't have that. He could only have kids' things.

"If he was only a shepherd he could have some lambs. He had once had a tame weasel and it was the dearest thing, but you couldn't pet a weasel, although you could get to love it, and feel as if the world had come to an end when it died.

"But there was always one Christmas that he remembered. He had got a lot of things that day, but when night came he was so tired, that he had a fight with his brother. Oh, not a real fight, you know; only the kind that brothers always have. People may think you awful, and send you off to bed, but 
half the time you don't know what's the matter. Why, that was only last Christmas? Do you remember that night, Mo-ma?" "Perfectly."

"We were at home in the city," he continued. "You had come up to my room and sat by me. I was all covered up with the quilt, so you wouldn't see my red eyes. All at once we heard some one singing. It was only Mamma and Aida. Mamma was playing the air on the dear violin, Aida accompanying her on the piano and singing, and she always gives one a chance to hear the words."

"Yes, Edwy, I remember. You flew out of bed and leaned over the banisters to hear. It was from The Oratorio of the 'Messiah.' You wished they would play and sing it all night. You had forgotten all your troubles in a moment."

"Oh, I can hear it now, even after all these months, as the remembrance of it comes 


\section{6}

through the still evening air. 'He shall feed his flock ... feed his flock . . . like a shepherd. He shall carry the lambs in his bosom, and shall gently lead those that are with young.' Then you told me the story about His life, after I came back to bed, and I fell asleep, saying it over and over. He shall feed his flock ... feed his flock ... like a shepherd ... and carry the lambs in his bosom ... the little . . little . . lambs!" 


\section{CHAPTER VI}

DEPARTURE OF THE FIRST GROUP OF CAMPERS

EDwy's special friend had noticed how bravely he had given up the idea of taking any of the country pets to the city, at least until he grew older, but there was one little plan which she had not as yet divulged to anybody. She had remarked to herself that a kitten had not been forbidden, simply because it had not been thought of as a possibility. After the boys and their parents had said good-bye to their camp, and the whistle of their train could be heard far over the hills, she began to take a new course with Zephyr. The little lonesome creature would go often down to the bank, and seem to watch for the coming of a boat and a wel- 


\section{8}

coming warwhoop, but would always come back disappointed. It was at such times that Aida and her mother would have a loving word for Zephyr, and it evidently was at a loss to know what such unusual attention meant. For instance, Zephyr might have wondered why she was so often invited to go to sleep in a large cushioned box, with a wire cover, not often closed, over her; and why she was fed occasional dainties in this place, until she had grown to love it, and feel perfectly at home in it.

Up to this time, they had not been quite sure but that some one might claim Zephyr, but they had found out by accident, that a family had moved away from a near-by hamlet, and had left this helpless creature to the mercy of fierce dogs and winter terrors; but a kind Providence that doth not let even the sparrows fall had brought her to a good home, and now, that it had been decided what could be done for her by the remain- 
ing friends at the camp, there was no lack of affection shown. So Zephyr grew soft and fluffy and more engaging than ever, had no fear of her wire-covered box, in which she was being prepared for a longer journey, and eventually for summers and winters to come. In this way she might be brought back and forth to the camp every summer.

Some weeks had passed befo e the second army of campers were ready to leave. The autumn days had turned the leaves of the forest from gold to crimson, the Hermit thrush had ceased its song of the even-tide, and when they were all ready to leave the camp, Zephyr did not seem at all surprised to be taken along with them. She was taken to Aida's home at first, for her (Aida's) tall husband had at last come home, braving the dangers of the war-ravaged seas. 


\section{CHAPTER VII}

ONE OF ZEPHYR'S SUMMER HOMES

As Aida's real summer home was in a lovely small city in one of the more northern belts of the state, she would not go to the great city for a month yet. So this country house, the Blake home, happened to be Zephyr's first stopping place. While mother and daughter, in the quiet of the home garden, had many a talk under the trees about the friends who had preceded them to that great city, which has always welcomed its own people; and also the oppressed of all nations, and honored them so long as the privileges of citizenship were appreciated. To those who seemed to understand intui- 


\section{I}

tively that the "Statue of Liberty," presented by a sister nation, meant more of friendship, loyalty, and respect, than words could express, it was a most wonderful boon, and at once the "Empire city" seemed to become law-abiding, by absorption, under the leadership of the great souls who ruled both city and country, and their appreciation of this new and lasting bond.

While Aida and her mother were happy in the garden and thinking "Big thoughts," Edwy's pretty name for all he could not quite comprehend, Aida, looking up, saw a shadow pass over her mother's face.

"If Edwy were here, dearest, he would ask his friend, why? And he would wait for you to answer his loving question, but I think I know."

"How do any of us know, when our boys come to be grown men, what may they not have to do to hold such liberty sacred? Can we be sure that their beautiful lives might 
not have to pay the toll of enrollment for their sacred trust-for their country?"

It was a thought she would not leave in a moment.

"If both boys were here, dear, they would remind you of the Shepherd's story, which you have so often told them."

By way of taking her mind from life's strange vicissitudes, Aida called her attention to the fact of Zephyr's disappearance. Where could it have gone?

The little creature never seemed to have felt quite so much at home as at the North. It had missed the lake, the boats and the merry voices of the two boys, as they came between the two camps, with the sound of beating oars. Sure enough, Zephyr had gone without even touching her breakfast.

Just at that moment a little girl came along the garden walk, stepping over the bank beside Aida's lovely flowers, many of them still blooming although so late in the autumn. 
"I've brought your Kitty home," she said gently. "But she loves to stay right in my arms. I found her in the schoolroom, and I don't believe she would have been afraid of any of the boys for they all petted her, but the teacher was having them say some dates in unison, and it made such a racket that she came running to me, and I knew just who owned her, for I had seen her in your garden."

"O, thank you a thousand times! Zephyr shall know you as her little friend."

"May I take her to school again?"

"Every day if you wish, and play with her here, too, under the trees."

"What were the dates that the scholars were saying in unison?" the mother asked.

"One was the date on which the beautiful Statue of Liberty came from France with its motto, 'Liberty Enlightening the World.' "

"Just what we were talking about, dear," said the mother thoughtfully. "Ever since its 


\section{4}

arrival, it has been wreathed with loving, and often poetic thought, and I am glad that our schools are asking you to remember the dates of great events.

"While we are staying here she can go to school with you every day, and you are welcome here, too, among Aida's flowers!" 


\section{CHAPTER VIII}

\section{A SURPRISE}

WINTER had really come at last, the snowflakes had covered the brown fields, and time was fast hastening on to bring the great day of all the year, Christmas day. Aida had sent gifts that she knew they would like, their Uncle had brought them some gifts from Paris, and this special friend of theirs had her own plan, that made her smile to herself, when she thought how Edwy loved things that he could pet and fondle and call his own. The other presents had all been sent early to their city home, and messages of thanks had been sent back, but the question had been flashed back to the senders: 


\section{6}

"Why didn't you come yourselves? Christmas day is never Christmas day, unless you are here!"

But it was almost over, and, as yet, not any sign of the rest of the group as the slow hours passed.

All at once there was a loud sound of tramping in the hall, then a shout of welcome in the air, and Edwy hoped it might be one person .... no, two, whom he loved, and who loved him. And sure enough, he was not disappointed. Aida was there, and right behind her Edwy's friend appeared on the scene, all trim and fine, her eyes full of love; and before they knew it, she had made a pounce upon Edwy, and the next moment had him in her arms.

She said nothing about a wire-covered box that stood in the hall, but seeing it accidentally after he had given her a good hug, "a real bear-hug," he said:

"Oh, you've brought down one of my box- 


\section{7}

traps. Is it one of them? But we don't need any box-traps here, for there's nothing to catch."

But Willard, by this time, had torn off the cover. ... The box was opened wide at last, and oh! wonder of wonders! here was the little white cat, their beautiful Zephyr, looking up at them with questioning eyes. ,

The shout that went up ended suddenly with the peculiarly happy screech of an Indian warwhoop, a sound they had not heard from Edwy's lips for many a month. Instead of jumping out of her box at once, Zephyr sat up on her cushion, and began to wash her face with her velvet paw, and when she saw Edwy, she began at once that hightoned purr, as if to show her gratitude, that after her long journey, she had found her friends. Her next act was to jump out of her box, after one look at their glad faces, and another glance from floor to ceiling and from ceiling to floor, she started on a wild 


\section{8}

chase after one of the Christmas apples, that had rolled out on the floor.

The boy and the cat now had their race of pure delight from room to room. While the grace of her motions seemed the most wonderful in the world, making all the people laugh, the rapt happy look on Edwy's face was a greater joy. It was a marvel of expression.

Zephyr was his very own, to keep always! 





\section{LIBRARY OF CONGRESS \\ IIIIII)

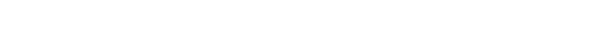 \\ 00025609979}

